\title{
Reduction of pasteurization temperature leads to lower bacterial outgrowth in pasteurized fluid milk during refrigerated storage: A case study
}

\author{
N. H. Martin, M. L. Ranieri, M. Wiedmann, and K. J. Boor ${ }^{1}$ \\ Milk Quality Improvement Program, Department of Food Science, Cornell University, Ithaca, NY 14853
}

\begin{abstract}
Bacterial numbers over refrigerated shelf-life were enumerated in high-temperature, short-time (HTST) commercially pasteurized fluid milk for 15 mo before and $15 \mathrm{mo}$ after reducing pasteurization temperature from $79.4^{\circ} \mathrm{C}\left(185^{\circ} \mathrm{F}\right)$ to $76.1^{\circ} \mathrm{C}\left(169^{\circ} \mathrm{F}\right)$. Total bacterial counts were measured in whole fat, $2 \%$ fat, and fat-free milk products on the day of processing as well as throughout refrigerated storage $\left(6^{\circ} \mathrm{C}\right)$ at 7,14 , and $21 \mathrm{~d}$ postprocessing. Mean total bacterial counts were significantly lower immediately after processing as well as at $21 \mathrm{~d}$ postprocessing in samples pasteurized at $76.1^{\circ} \mathrm{C}$ versus samples pasteurized at $79.4^{\circ} \mathrm{C}$. In addition to mean total bacterial counts, changes in bacterial numbers over time (i.e., bacterial growth) were analyzed and were lower during refrigerated storage of products pasteurized at the lower temperature. Lowering the pasteurization temperature for unflavored fluid milk processed in a commercial processing facility significantly reduced bacterial growth during refrigerated storage.
\end{abstract}

Key words: pasteurization temperature, milk, sporeforming bacteria

\section{INTRODUCTION}

The public health objective of milk pasteurization, as defined in the 2009 Pasteurized Milk Ordinance (PMO; FDA, 2009), is to eliminate all non-spore-forming human pathogens commonly associated with raw milk. The PMO specifies heating milk to a minimum of $72^{\circ} \mathrm{C}$ for $15 \mathrm{~s}$ to achieve HTST pasteurization. In the absence of postpasteurization contamination (PPC), the microorganisms that limit fluid milk shelf-life are the sporeforming bacteria Bacillus spp. and Paenibacillus spp. (Fromm and Boor, 2004; Durak et al., 2006; Huck et al., 2007b, 2008). These organisms are found ubiquitously in different environments and can enter the raw milk supply at various points (Huck et al., 2008). Although

Received August 10, 2011.

Accepted September 18, 2011.

${ }^{1}$ Corresponding author: kjb4@cornell.edu several spore-formers can survive HTST pasteurization in spore form (Collins, 1981; Huck et al., 2007a), not all can reproduce in fluid milk at refrigeration temperatures. For example, although many Paenibacillus spp. isolates obtained from milk processing systems can grow in milk at temperatures around $6^{\circ} \mathrm{C}$, relatively few Bacillus spp. isolates are able to do so (Fromm and Boor, 2004; Ranieri and Boor, 2009). The shift in the microbial ecology of refrigerated pasteurized milk from predominantly Bacillus spp. in freshly pasteurized milk to Paenibacillus spp. after approximately $14 \mathrm{~d}$ (Fromm and Boor, 2004; Ranieri et al., 2009) implicates the presence of Paenibacillus spp. in pasteurized milk as an important cause of fluid milk spoilage in the absence of PPC.

It is common for HTST pasteurization to be performed above the minimum parameters stipulated by the PMO (Fromm and Boor, 2004; Huck et al., 2007b; Martin et al., 2011). Further, in response to food safety concerns raised in the early 2000s, many milk processors raised pasteurization temperatures well above minimal levels. However, several processors anecdotally reported increased numbers of consumer complaints about milk spoilage after pasteurization temperatures were increased (Ranieri et al., 2009). A controlled study designed to measure the effects of pasteurization temperatures on postpasteurization bacterial outgrowth showed that milk processed at higher HTST temperatures had greater bacterial outgrowth during refrigerated storage than milk processed at lower temperatures (Ranieri et al., 2009). In response to the Ranieri et al. (2009) study, a small-scale New York State dairy processor reduced its HTST pasteurization temperature from $79.4^{\circ} \mathrm{C}\left(185^{\circ} \mathrm{F}\right)$ to $76.1^{\circ} \mathrm{C}\left(169^{\circ} \mathrm{F}\right)$. In this report, we compare bacterial numbers in commercial fluid milk processed before and after the change in pasteurization temperature.

\section{MATERIALS AND METHODS}

\section{Sample Processing and Plant Characteristics}

Raw milk processed at the small-scale, New York State licensed dairy processing facility was obtained 
from a single farm. Approximately 1.5 million lbs of raw milk are processed into fluid milk and other products each year at the facility.

Raw and pasteurized milk samples were collected from the processing facility once a week for $30 \mathrm{mo}$. Processing conditions during the first 15 mo were $79.4^{\circ} \mathrm{C}$ $\left(185^{\circ} \mathrm{F}\right)$ for $18.25 \mathrm{~s}$. During the second 15 -mo period, processing conditions were $76.1^{\circ} \mathrm{C}\left(169^{\circ} \mathrm{F}\right)$ for $18.25 \mathrm{~s}$. Pasteurized samples included (1) whole-fat milk packaged in half-gallon (1.89-L) plastic or 10-oz (295-mL) paperboard; (2) $2 \%$ milk packaged in half-gallon (1.89L) plastic or 10-oz (295-mL) paperboard; and (3) skim milk packaged in half-gallon (1.89-L) plastic or $10-\mathrm{oz}$ (295-mL) paperboard.

\section{Microbiological Analysis of Raw and Pasteurized Milk}

Raw milk representing each processing day was obtained in $2-\mathrm{oz}(59-\mathrm{mL})$ vials from the processing facility before pasteurization. Milk was evaluated for total bacteria count by spiral plating on SPC medium (Difco, BD Diagnostics, Franklin Lakes, NJ) according to Standard Methods for the Examination of Dairy Products (Frank and Yousef, 2004) and coliform bacteria count on Petrifilm Coliform Count plates according to the manufacturer's instructions (3M, St. Paul, MN). Petrifilm and SPC plates were incubated at $32^{\circ} \mathrm{C}$ for 24 and $48 \mathrm{~h}$, respectively.

All samples of whole-fat, $2 \%$ fat, and fat-free pasteurized milk were obtained from the processing facility on the day of processing in original 10-oz (295-mL) paperboard and half-gallon (1.89-L) plastic containers and held in those original containers at $6^{\circ} \mathrm{C}$ throughout shelf-life testing. Samples were evaluated on the initial day as well as on d 7, 14, and 21 postprocessing for total aerobic bacterial count on SPC agar and coliform bacteria count as described above for raw milk.

\section{Statistical Analysis}

All statistical analyses were performed in JMP (version 7.0, SAS Institute Inc., Cary, NC). Microbiological data were log-transformed before performing ANOVA on bacterial numbers by day of shelf-life. Analysis of variance was also performed on bacterial growth by day of shelf-life, which was calculated by subtracting the total bacterial counts on the initial day from the total bacterial counts on d 7, 14, and 21. Pearson $\chi^{2}$ was used to determine if a significant difference existed between the counts of samples with less than the PMO limit of $20,000 \mathrm{cfu} / \mathrm{mL}$ before and after the temperature change at each day of shelf-life. Results are presented as percentages for ease of interpretation.

\section{RESULTS AND DISCUSSION}

Using a small, licensed fluid milk processing plant that already produced high-quality fluid milk products with rare instances of postpasteurization contamination, we tested the hypothesis that reduced HTST temperatures that are still above the legal temperature of $72^{\circ} \mathrm{C}$ can further improve product quality and shelf life. This hypothesis was based on previous laboratory studies (Ranieri et al., 2009) that showed that a reduction in HTST pasteurization temperatures leads to reduced microbial growth in fluid milk stored under refrigeration temperatures.

\section{High-Quality Raw Milk in Combination with the Absence of Postprocessing Contamination Results in High-Quality Pasteurized Milk}

The plant used for this study used a high-quality raw milk supply. Total bacterial counts in raw milk throughout the study period were below the PMO limit of $300,000 \mathrm{cfu} / \mathrm{mL}$ for commingled milk (FDA, 2009) with a mean of $3,800 \mathrm{cfu} / \mathrm{mL}$ and a maximum of $150,000 \mathrm{cfu} / \mathrm{mL}$. High-quality raw milk should have an SPC count $<10,000 \mathrm{cfu} / \mathrm{mL}$ (Murphy and Boor, 2000), and of the 181 raw milk samples in this study, $75.7 \%$ had SPC counts $<10,000 \mathrm{cfu} / \mathrm{mL}$. The raw milk sampled in this study had a mean coliform count of $21 \mathrm{cfu} /$ $\mathrm{mL}$, with a maximum of $540 \mathrm{cfu} / \mathrm{mL}$, consistent with a previous study, which showed that $77 \%$ of 855 raw milk producer bulk tank samples from individual farms in New York State had a coliform count $<100 \mathrm{cfu} /$ $\mathrm{mL}$ (Boor et al., 1998). Although the PMO does not specify a regulatory limit for coliform numbers in raw milk, producer bulk tank raw milk samples have been reported to range from 5 to $4,130 \mathrm{cfu} / \mathrm{mL}$ (Jayarao and Wang, 1999). Raw milk with a coliform count of $<50$ $\mathrm{cfu} / \mathrm{mL}$ is generally considered high quality (Murphy and Boor, 2000), and among the 181 raw milk samples in this study, $75.7 \%$ had coliform counts $<50 \mathrm{cfu} / \mathrm{mL}$.

The PMO specifies that grade "A" pasteurized milk have a SPC count of $<20,000 \mathrm{cfu} / \mathrm{mL}$ and a coliform count of $\leq 10 \mathrm{cfu} / \mathrm{mL}$ throughout product shelf-life (FDA, 2009). Throughout this study (i.e., before and after implementation of a reduced HTST temperature), the pasteurized milk produced by the plant that was used for the study was of high quality with evidence of limited postpasteurization contamination. The microbiological tests conducted on all 604 pasteurized milk samples in this study show that on the initial day of 
testing none of the samples exceeded the 20,000 $\mathrm{cfu} /$ $\mathrm{mL}$ limit. On d 7, 14, and 21 postprocessing, 98.5, 81.3, and $46.5 \%$ of samples, respectively, did not exceed this limit (see Table 1, which includes percentage of samples $<20,000 \mathrm{cfu} / \mathrm{mL}$ before and after implementation of the change in HTST temperature). For comparison, a previous study evaluating HTST milk quality from 23 processing facilities in New York State over a 10-yr period showed that at d 7 postprocessing, 46 to $66 \%$ of samples per year had not exceeded the regulatory of limit of $20,000 \mathrm{cfu} / \mathrm{mL}$ and at d 14 the range was 12 to $32 \%$ (Carey et al., 2005).

We also found that none of the 604 pasteurized milk samples had coliform contamination on the initial day of testing or at d 7, 14, or 21 postprocessing. Because of the heat-sensitive nature of coliforms, the presence of these organisms in pasteurized milk would be indicative of PPC. Certain coliform bacteria, along with other heat-labile gram-negative rods that enter milk following pasteurization, can grow to spoilage levels within as few as $7 \mathrm{~d}$ after pasteurization, even under refrigerated storage conditions (Dogan and Boor, 2003). Spoilage due to PPC remains a major cause of fluid milk spoilage (Carey et al., 2005; Ranieri and Boor, 2009; Martin et al., 2011). With stringent cleaning and sanitation programs in place, processing facilities can reduce and control this type of contamination and extend the shelflife of their product to $17 \mathrm{~d}$ and beyond (Ranieri and Boor, 2009). In the absence of PPC, the microbes that limit pasteurized milk shelf-life are the gram-positive psychrotolerant spore-forming rods Bacillus spp. and Paenibacillus spp., which can enter the product in spore form along the milk-processing continuum and subsequently grow at refrigeration temperatures (Fromm and Boor, 2004; Durak et al., 2006; Huck et al., 2007b, 2008). In the present study, the combination of highquality raw milk with consistently low bacterial numbers and the absence of PPC resulted in almost half of the pasteurized milk samples remaining below the PMO limit of $20,000 \mathrm{cfu} / \mathrm{mL}$ at $21 \mathrm{~d}$ postprocessing (Table 1), indicating the ability of this processing plant to manufacture a consistently high-quality product.

\section{Statistical Analysis Indicates that Lowering Pasteurization Temperature Reduces Bacterial Growth in Fluid Milk over Shelf-Life}

Bacterial counts were significantly lower in milk pasteurized at $76.1^{\circ} \mathrm{C}$ than in milk pasteurized at $79.4^{\circ} \mathrm{C}$ on both the initial test day and at $21 \mathrm{~d}$ postprocessing (Figure 1). For fluid milk samples processed at the higher pasteurization temperature, mean bacterial counts on the initial day were $1.58 \log \mathrm{cfu} / \mathrm{mL}$, significantly higher $(P<0.0001)$ than the count $(1.39$
Table 1. Samples with $<20,000 \mathrm{cfu} / \mathrm{mL}$ by day of shelf-life for milk pasteurized at 76.1 and $79.4^{\circ} \mathrm{C}$

\begin{tabular}{lccc}
\hline & \multicolumn{2}{c}{ Samples $<20,000 \mathrm{cfu} / \mathrm{mL}, \%$} & \\
\cline { 2 - 3 } $\begin{array}{l}\text { Day of } \\
\text { shelf-life }\end{array}$ & $76.1^{\circ} \mathrm{C}$ & $79.4^{\circ} \mathrm{C}$ & Total \\
\hline Initial & $100.0^{\mathrm{a}}$ & $100.0^{\mathrm{a}}$ & 100.0 \\
7 & $98.7^{\mathrm{a}}$ & $98.3^{\mathrm{a}}$ & 98.5 \\
14 & $87.7^{\mathrm{a}}$ & $74.3^{\mathrm{b}}$ & 81.3 \\
21 & $59.2^{\mathrm{a}}$ & $32.6^{\mathrm{b}}$ & 46.5 \\
\hline
\end{tabular}

$\overline{\mathrm{a}, \mathrm{b}}$ Different superscript letters between pasteurization temperatures by day of shelf-life indicates a significant difference in percentage of samples $<20,000 \mathrm{cfu} / \mathrm{mL}(P<0.0001)$.

${ }^{1}$ Indicates number of days postprocessing.

$\log \mathrm{cfu} / \mathrm{mL})$ in samples processed at the lower temperature. Similarly, bacterial counts at d 7, 14, and 21 postprocessing were significantly higher for the samples processed at the higher temperatures (Table 2). In addition to comparing the bacterial counts at each sampling day after processing, changes in bacterial numbers (i.e., bacterial growth) for the samples pasteurized at $76.1^{\circ} \mathrm{C}$ were compared with those in the samples pasteurized at $79.4^{\circ} \mathrm{C}$. A comparison of total bacterial growth over $21 \mathrm{~d}$ of refrigerated shelf-life (e.g., SPC counts at $21 \mathrm{~d}$ postprocessing minus SPC counts on the initial day) for the 2 pasteurization temperatures showed that the milk pasteurized at $76.1^{\circ} \mathrm{C}$ had significantly lower bacterial growth than the milk pasteurized at $79.4^{\circ} \mathrm{C}(P<$ $0.0001)$. The same was true when examining bacterial growth over 7 and $14 \mathrm{~d}(P<0.0001$ for both analyses).

Because factors other than the change in pasteurization temperatures may have affected the microbial quality of the finished products, we performed additional ANOVA that tested for the effects of other factors on finished product quality. We specifically tested whether, among the samples tested, the following factors had a significant effect on finished product quality: (1) microbial quality of the raw milk (as determined by SPC counts) and (2) change in processing plant personnel (the production supervisor position changed in August 2008). Neither factor showed a significant effect on finished product quality $(P=0.4242$ and $P=$ 0.6122 , respectively).

Reduced bacterial spoilage of fluid milk pasteurized at lower temperatures was reported previously by Ranieri et al. (2009); in contrast to the study reported here, that study used controlled conditions; that is, a given batch of raw milk was pasteurized at different temperatures in a pilot-scale pasteurizer. The current study shows that the findings from this previous laboratory study extrapolate to commercial processing conditions.

Many different factors can affect bacterial growth during refrigerated storage (Gounot, 1991; Champagne et al., 1994; Hayes and Boor, 2001; Chin et al., 2010). One critical factor may be the amount of residual lac- 
Table 2. Mean bacterial counts by day of shelf-life for milk pasteurized at 76.1 and $79.4^{\circ} \mathrm{C}$

\begin{tabular}{lccc}
\hline & \multicolumn{3}{c}{$\begin{array}{c}\text { Mean bacterial count, } \\
\text { log cfu } / \mathrm{mL}\end{array}$} \\
\cline { 2 - 3 } $\begin{array}{l}\text { Day of } \\
\text { shelf-life }\end{array}$ & $76.1^{\circ} \mathrm{C}$ & $79.4^{\circ} \mathrm{C}$ & \multirow{2}{*}{$P$-value } \\
\hline Initial & $1.39^{\mathrm{a}}$ & $1.58^{\mathrm{b}}$ & $<0.0001$ \\
7 & $1.49^{\mathrm{a}}$ & $1.82^{\mathrm{b}}$ & $<0.0001$ \\
14 & $2.32^{\mathrm{a}}$ & $3.25^{\mathrm{b}}$ & $<0.0001$ \\
21 & $3.74^{\mathrm{a}}$ & $4.82^{\mathrm{b}}$ & $<0.0001$ \\
\hline
\end{tabular}

${ }^{a, b}$ Different superscript letters between pasteurization temperatures by day of shelf-life indicates a significant difference in mean bacterial counts.

${ }^{1}$ Indicates number of days postprocessing.

toperoxidase activity that remains following pasteurization. Lactoperoxidase is a naturally occurring enzyme in raw milk that functions as a bacteriostatic agent against both gram-positive and gram-negative bacteria (Reiter et al., 1976; Gaya et al., 1991). Lactoperoxidase is a heat-labile enzyme; approximately $90 \%$ of its activity remains in milk that has been heated for 2 min at $72^{\circ} \mathrm{C}$, but only $36 \%$ activity remains in milk heated at $76^{\circ} \mathrm{C}$ for $40 \mathrm{~s}$ (Marin et al., 2003). Complete destruction of the enzyme is achieved at $80^{\circ} \mathrm{C}$ for $15 \mathrm{~s}$ (Griffiths,
1986), a common HTST processing condition. The balance between achieving proper pasteurization to ensure inactivation of pathogens present in raw milk and optimizing processing conditions that limit the growth of spoilage bacteria can be accomplished by using pasteurization temperatures near the minimum specified.

\section{The Use of Simple Statistical Methods Provides Dairy Processors with Tools to Improve Product Quality}

As the beverage market becomes increasingly competitive, the dairy industry must consider utilizing tools that will allow them to identify and evaluate facility and process areas that need improvement. This can be done using simple statistical methods, as illustrated in this study. Even processors with limited resources can pair their own shelf-life testing with simple statistical tools to provide a scientific approach to in-house troubleshooting and process optimization for continual quality improvement.

Another benefit of using statistical analyses for inhouse dairy process optimization and troubleshooting is the ability to identify factors that specifically contribute to the issue under investigation when multiple

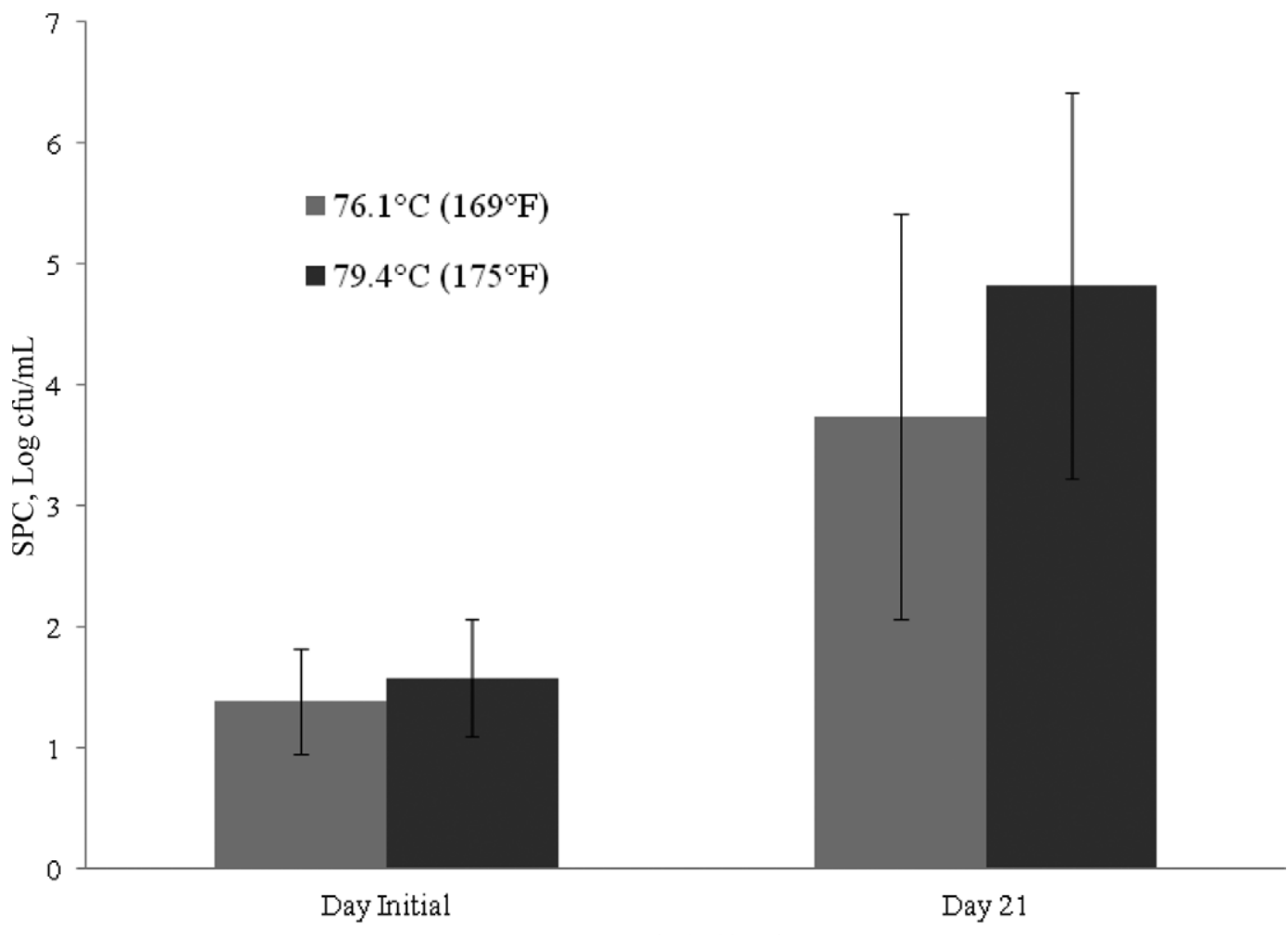

Day of Shelf Life

Figure 1. Total aerobic SPC for whole, $2 \%$, and skim milk pasteurized at 76.1 and at $79.4^{\circ} \mathrm{C}$ and held at $6^{\circ} \mathrm{C}$ for $21 \mathrm{~d}$ postprocessing. Data represent mean $\mathrm{SPC}$ counts and bars indicate mean $\pm 1 \mathrm{SD}$ for each temperature. 
factors potentially play a role. For example, in our study, we were able to determine whether raw milk quality, personnel changes, pasteurization temperature, or some combination of these factors, had a role in the reduction of bacterial numbers and growth in milk pasteurized at different temperatures. The ability to focus efforts on significant issues saves time, money, and other valuable resources, all of which are critical to the dairy industry.

\section{ACKNOWLEDGMENTS}

This project was supported by the New York State Milk Promotion Advisory Board through the New York State Department of Agriculture and Markets-NYS dairy farmers committed to production of high quality dairy products. The authors thank the staff and students of the Milk Quality Improvement Program (Cornell University, Ithaca, NY) for assistance with this study.

\section{REFERENCES}

Boor, K. J., D. P. Brown, S. C. Murphy, S. M. Kozlowski, and D. K. Bandler. 1998. Microbiological and chemical quality of raw milk in New York State. J. Dairy Sci. 81:1743-1748.

Carey, N. R., S. C. Murphy, R. N. Zadoks, and K. J. Boor. 2005. Shelf lives of pasteurized fluid milk products in New York State: A tenyear study. Food Prot. Trends 25:102-113.

Champagne, C. P., R. R. Laing, D. Roy, A. A. Mafu, and M. W. Griffiths. 1994. Psychrotrophs in dairy products: Their effects and their control. Crit. Rev. Food Sci. Nutr. 34:1-30.

Chin, J. P., J. Megaw, C. L. Magill, K. Nowotarski, J. P. Williams, P. Bhaganna, M. Linton, M. F. Patterson, G. J. C. Underwood, A. Y. Mswaka, and J. E. Hallsworth. 2010. Solutes determine the temperature windows for microbial survival and growth. Proc. Natl. Acad. Sci. USA 107:7835-7840.

Collins, E. B. 1981. Heat-resistant psychrotrophic organisms. J. Dairy Sci. 64:157-160.

Dogan, B., and K. J. Boor. 2003. Genetic diversity and spoilage potentials among Pseudomonas spp. isolated from fluid milk products and dairy processing plants. Appl. Environ. Microbiol. 69:130138.

Durak, M. Z., H. I. Fromm, J. R. Huck, R. N. Zadoks, and K. J. Boor. 2006. Development of molecular typing methods for Bacillus spp. and Paenibacillus spp. isolated from fluid milk products. J. Food Sci. 71:50-56.
FDA. 2009. Standards for grade "A" milk and milk products. 28-31 in Grade "A" Pasteurized Milk Ordinance. Standards for grade "A" milk and milk products. US Department of Health and Human Services, Public Health Service, Washington, DC.

Frank, J. F., and A. E. Yousef. 2004. Tests for groups of microorganisms. Pages 227-248 in Standard Methods for the Examination of Dairy Products. 17th ed. H. M. Wehr and J. F. Frank, ed. Am. Public Health Assoc., Washington, DC.

Fromm, H. I., and K. J. Boor. 2004. Characterization of pasteurized fluid milk shelf-life attributes. J. Food Sci. 69:207-214.

Gaya, P., M. Medina, and M. Nunez. 1991. Effect of the lactoperoxidase system on Listeria monocytogenes behavior in raw milk at refrigeration temperatures. Appl. Environ. Microbiol. 57:33553360 .

Gounot, A. M. 1991. A review. Bacterial life at low temperature: Physiological aspects and biotechnological implications. J. Appl. Bacteriol. 71:386-397.

Griffiths, M. W. 1986. Use of milk enzymes as indices of heat treatment. J. Food Prot. 49:696-705.

Hayes, M. C., and K. Boor. 2001. Raw milk and fluid milk products. Pages 59-76 in Applied Dairy Microbiology. 2nd ed. E. H. Marth and J. L. Steele, ed. Marcel Dekker Inc., New York, NY.

Huck, J. R., B. H. Hammond, S. C. Murphy, N. H. Woodcock, and K. J. Boor. 2007a. Tracking spore-forming bacterial contaminants in fluid milk-processing systems. J. Dairy Sci. 90:4872-4883.

Huck, J. R., M. Sonnen, and K. J. Boor. 2008. Tracking heat-resistant, cold-thriving fluid milk spoilage bacteria from farm to packaged product. J. Dairy Sci. 91:1218-1228.

Huck, J. R., N. H. Woodcock, R. D. Ralyea, and K. J. Boor. 2007b. Molecular subtyping and characterization of psychrotolerant endospore-forming bacteria in two New York State fluid milk processing systems. J. Food Prot. 70:2354-2364.

Jayarao, B. M., and L. Wang. 1999. A study on the prevalence of gramnegative bacteria in bulk tank milk. J. Dairy Sci. 82:2620-2624.

Marin, E., L. Sanchez, M. D. Perez, P. Puyol, and M. Calvo. 2003. Effect of heat treatment on bovine lactoperoxidase activity in skim milk: Kinetic and thermodynamic analysis. J. Food Sci. 68:89-93.

Martin, N. H., M. L. Ranieri, S. C. Murphy, R. D. Ralyea, M. Wiedmann, and K. J. Boor. 2011. Results from raw milk microbiological tests do not predict the shelf-life performance of commercially pasteurized fluid milk. J. Dairy Sci. 94:1211-1222.

Murphy, S. C., and K. J. Boor. 2000. Troubleshooting sources and causes of high bacteria counts in raw milk. Dairy Food Environ. Sanit. 20:606-611.

Ranieri, M. L., and K. J. Boor. 2009. Short communication: Bacterial ecology of high-temperature, short-time pasteurized milk processed in the United States. J. Dairy Sci. 92:4833-4840.

Ranieri, M. L., J. R. Huck, M. Sonnen, D. M. Barbano, and K. J. Boor. 2009. High temperature, short time pasteurization temperatures inversely affect bacterial numbers during refrigerated storage of pasteurized fluid milk. J. Dairy Sci. 92:4823-4832.

Reiter, B., V. M. Marshall, L. Bjorck, and C. G. Rosen. 1976. Nonspecific bactericidal activity of the lactoperoxidases-thiocyanate-hydrogen peroxide system of milk against Escherichia coli and some gram-negative pathogens. Infect. Immun. 13:800-807. 